Original Research Article

\title{
Knowledge, attitude and practices about adverse drug reaction among medical students in a medical college: an observational study
}

\author{
Roshi*, Vishal R. Tandon, Brij M. Gupta
}

Department of Pharmacology, Govt. Medical College, Jammu, Jammu and Kashmir, India

Received: 06 May 2019

Accepted: 05 June 2019

*Correspondence to:

Dr. Roshi,

Email: roshigupta1986

@gmail.com

Copyright: (C) the author(s), publisher and licensee Medip Academy. This is an openaccess article distributed under the terms of the Creative Commons Attribution NonCommercial License, which permits unrestricted noncommercial use, distribution, and reproduction in any medium, provided the original work is properly cited.

\begin{abstract}
Background: Adverse Drug Reactions (ADRs) are usually associated with drugs which may or may not go unnoticed. ADRs are of great concern for any health care set up as they directly or indirectly add to the cost of treatment, prolongation of treatment, hospital stay or sometimes may even cause death. Spontaneous ADR reporting forms an important part of pharmacovigilance.

Methods: An observational study was carried out in a medical college to know the knowledge, attitude and practice being followed by them in a Medical College.

Results: In present study all the students had knowledge about ADRs. Only $86.7 \%$ of the students knew how and where to report an ADR. $73.3 \%$ of the students knew who can report an ADR and they had visited ADRM centre but only $60 \%$ of the students knew which ADR is to be reported. $88 \%$ of the students had an attitude that it is important to report an ADR and $86.7 \%$ told that it is useful to report an ADR. 99.3\% of the students had never reported an ADR. Only $1.4 \%$ of the students had really visited ADRM centre of their institution but none of the students had ever visited wards or OPDs to look for ADRs. 26.7\% of the students said that they will report an ADR if they see it ever.

Conclusions: There is good knowledge about ADRs and ADRM centre among students, but it needs to bring ADR reporting into practice by actively doing hands on workshops or by adding this exercise into practical curriculum.
\end{abstract}

Keywords: Adverse drug reaction, Awareness practice, Pharmacovigilance

\section{INTRODUCTION}

Every drug can act as a poison if not used judiciously as no drug is free of adverse drug reactions (ADRs). Globally, ADRs are of great significance because of their increasing incidence. ${ }^{1}$ According to World Health Organisation, ADRs is defined as any noxious change that is suspected to be due to drug, occurs in doses normally used in man, requires treatment or decrease in dose, or indicates caution in future use of same drug. ${ }^{2}$ ADRs are associated with drug-related patient morbidity by causing a prolonged length of hospital stay, higher economic burden, and sometimes mortality. They are a common and often preventable cause of hospital admission. The worldwide incidence of ADR incidence driving to emergency hospitalization varies from $0.2 \%$ to $41.3 \%$, while $28.9 \%$ of these ADRs are preventable. ${ }^{3}$ Moreover, more than $50 \%$ of approved drugs are linked with some adverse effects that are not recognized before their approval for clinical use. ${ }^{4}$ Therefore, detection and monitoring of ADRs are of vital importance for patient safety. Pharmacovigilance (PV) is defined as the science and activities relating to the detection, assessment, understanding, and prevention of adverse effects or any other drug-related problem. ${ }^{5}$ Its intention is to get the maximum benefit out of treatment. ${ }^{6}$ The objective of PV is to identify the ADR, establish causality, identify a potential signal and take a prompt 
action. This can be either banning a drug, decrease its dose, issue a warning with its use etc. The spontaneous ADR reporting is the mainstay of the Indian drug safety evaluation in the postapproval phase. ${ }^{7}$ Therefore, all health-care institutes such as medical, dental, pharmacy, nursing, and paramedical associated with patients need to make collective and continued efforts to encourage ADR reporting by providing safe and effective medication. All the medical students, doctors, nurses, pharmacists, health care workers, and even the patient should know about ADR and its reporting. Some ADRs may even require medical treatment or hospitalization. Thus, the present study was conducted to assess the knowledge, attitude, and practice (KAP) of PV among medical students in a Medical College to know the current status of the adverse drug reporting system in India.

\section{METHODS}

An observational study was carried out in a medical college to know the knowledge, attitude and practice being followed by them regarding adverse drug reaction. Permission was sought from Institutional Ethics Committee Government Medical College, Jammu, Jammu and Kashmir, India. The study was done in the month of May. It was a cross sectional study. A prevalidated questionairre was circulated among second year medical graduates and they were asked to fill it. Nature and purpose of study was explained. The questionairre was taken back after 20 minutes and were assessed. The data was assessed and tabulated.

\section{Inclusion Criteria}

All the second-year medical students (150 students).

A questionnaire was made in the vernacular language comprising of questions regarding knowledge, attitude and practice regarding adverse drug reactions. It was circulated among the said group of students and they were asked to fill it. Filled questionnaire were assessed and the data was expressed in percentage.

\section{RESULTS}

In present study all the students had knowledge about ADRs. Only $86.7 \%$ of the students knew how and where to report an ADR. $73.3 \%$ of the students knew who can report an ADR but only $60 \%$ of the students knew which ADR is to be reported. $73.3 \%$ of the students had visited the ADRM Centre of their college (Table 1).

There were $88 \%$ of the students had an attitude that it is important to report an ADR and $86.7 \%$ told that it is useful to report an ADR (Table 2). $99.3 \%$ of the students had never reported an ADR. Only $1.4 \%$ of the students had really visited ADRM Centre of their institution. None of the students had ever visited wards or OPDs to look for ADRs. $26.7 \%$ of the students said that they will report an ADR if they see it ever (Table 3).
Table 1: Knowledge about ADRs.

\begin{tabular}{|c|c|c|}
\hline Question & No. & $\%$ \\
\hline \multicolumn{3}{|c|}{ Do you know what is ADR? } \\
\hline Yes & 150 & 100 \\
\hline No & 0 & 0 \\
\hline \multicolumn{3}{|c|}{ Do you know how to report ADR? } \\
\hline Yes & 130 & 86.7 \\
\hline No & 20 & 13.3 \\
\hline \multicolumn{3}{|c|}{ If yes, have you any idea when to report ADR } \\
\hline Yes & 100 & 66.7 \\
\hline No & 50 & 33.3 \\
\hline \multicolumn{3}{|c|}{ Do you know where to report ADR } \\
\hline Yes & 130 & 86.7 \\
\hline No & 20 & 13.3 \\
\hline \multicolumn{3}{|c|}{ Do you know who can report ADR } \\
\hline Yes & 110 & 73.3 \\
\hline No & 40 & 26.7 \\
\hline \multicolumn{3}{|c|}{ Do you know which ADR to be reported } \\
\hline Yes & 90 & 60 \\
\hline No & 60 & 40 \\
\hline \multicolumn{3}{|c|}{ Are you aware of ADRM center in your college? } \\
\hline Yes & 110 & 73.3 \\
\hline No & 40 & 26.7 \\
\hline
\end{tabular}

Table 2: Attitude about ADRs.

\begin{tabular}{|lll|}
\hline Question & No. & $\%$ \\
\hline Do you think it's important to report ADR? & \\
\hline Yes & 132 & 88 \\
\hline No & 18 & 12 \\
\hline Do you think reporting an ADR is useful? & & \\
\hline Yes & 130 & 86.7 \\
\hline No & 20 & 13.3 \\
\hline
\end{tabular}

Table 3: Practice about ADRs.

\begin{tabular}{|lcl|}
\hline Question & No. & $\%$ \\
\hline Have you ever reported an ADR? & \multicolumn{1}{l|}{} \\
\hline Yes & 1 & 0.7 \\
\hline No & 149 & 99.3 \\
\hline Have you ever visited ADRM Centre of your college? \\
\hline Yes & 2 & 1.4 \\
\hline No & 148 & 98.6 \\
\hline Have you ever seen an ADR in a patient? & \\
\hline Yes & 30 & 20 \\
\hline No & 120 & 80 \\
\hline Have you ever visited wards to look for ADRs? \\
\hline Yes & 0 & 0 \\
\hline No & 150 & 100 \\
\hline $\begin{array}{l}\text { Would you report an ADR if there is an ADR in front } \\
\text { of you? }\end{array}$ \\
\hline No & 110 & 73.3 \\
\hline Yes & 40 & 26.7 \\
\hline
\end{tabular}




\section{DISCUSSION}

ADR reporting is the corner stone of pharmacovigilance programme of India. Underreporting of ADRs may lead to more serious harmful effects of drug. Health care workers, doctors and nurses should have knowledge where to report, how to report and when to report an ADR. In present study all the medical students were knowing about ADR. There are innumerable studies to evaluate the KAP of health care providers toward pharmacovigilance program, but a very few studies have been done among the budding doctors to capture their knowledge about same. . $^{-}$ 10 This study is one of the few studies done among undergraduate medical students regarding KAP of pharmacovigilance. In present study all the students had knowledge about ADRs. Only $86.7 \%$ of the students knew how and where to report an ADR. $73.3 \%$ of the students knew who can report an ADR but only $60 \%$ of the students knew which ADR is to be reported. $73.3 \%$ of the students had visited the ADRM Centre of their college. Medical students and doctors know more about ADRs in contrast to health care workers. ${ }^{11}$ Maxiumum of the students knew how and where to report an ADR. This was due to regular classes of the students about awareness on ADR. They had not visited ADRM Centre as they may have thought it to be a futile exercise since they think they are not the stakeholders in case of any ADR. $88 \%$ of the students had an attitude that it is important to report an ADR and $86.7 \%$ told that it is useful to report an ADR. $99.3 \%$ of the students had never reported an ADR. Only $1.4 \%$ of the students had really visited ADRM Centre of their institution. None of the students had ever visited wards or OPDs to look for ADRs. $26.7 \%$ of the students said that they will report an ADR if they see it ever. Various factors that discourage participants from ADR reporting despite having adequate knowledge include the belief that the ADR in question was already well known and common, the ADR is not serious and uncertainty concerning the causal relationship between the ADR and drug. Strategies to improve reporting of ADRs by including topics of PV in medical curriculum and educating them that any suspected ADRs are to be reported even if one is not sure about it. Other modalities to encourage HCPs to report ADRs include easy access to ADR forms, toll free numbers to contact $\mathrm{AMC}$ of the institution and CME activities to create the awareness about the building of Indian database of ADR and PV. These activities may reduce the barriers and misconceptions that discourage reporting of ADRs. All the three students felt that ADR reporting is necessary, and that PV should be taught in detail to them. It reveals a positive attitude of the participants and this finding is almost similar to previous studies. $^{12}$

\section{CONCLUSION}

There is a need to bring ADR reporting into practice by either making it compulsory for students to either report certain number of ADRS monthly or by adding this exercise into teaching curriculum. Hands on workshops or
Continued Medical Education Programmes should be conducted to create awareness about this programme. Limitations: Number of subjects was very less. More questions could have been added about reasoning for not doing the things

\section{Funding: No funding sources}

Conflict of interest: None declared

Ethical approval: The study was approved by the Institutional Ethics Committee

\section{REFERENCES}

1. Beard K. Adverse reactions as a cause of hospital admission in the aged. Drugs Aging. 1992;2(4):35667.

2. McDonnell PJ, Jacobs MR. Hospital admissions resulting from preventable adverse drug reactions. Ann Pharmacother. 2002; 36(9):1331-6.

3. Ramesh M, Pandit J, Parthasarathi G. Adverse drug reactions in a south Indian hospital-their severity and cost involved. Pharmacoepidemiol Drug Saf. 2003;12(8):687-92.

4. Bahekar SE, Patil SM. Evaluation of knowledge, attitude, and practice of adverse drug reactions reporting among doctors and nursing staff of a rural tertiary care teaching hospital of Maharashtra. J Med Sci Res 2018;1(3):145-50.

5. WHO Policy Perspectives on Medicines. Pharmacovigilance: ensuring the safe use of medicines. No. 009, 2004. Available at: http://apps.who.int/medicinedocs/pdf/s6164e/s6164e. pdf. Accessed 23 April 2018.

6. Ganesan S, Sandhiya S, Reddy KC, Subrahmanyam DK, Adithan C. The impact of the educational intervention on knowledge, attitude, and practice of pharmacovigilance toward adverse drug reactions reporting among health-care professionals in a tertiary care hospital in South India. J Nat Sci Biol Med. 2017;8(2):203-09.

7. Rawlins MD. Spontaneous reporting of adverse reactions. I: the data. $\mathrm{Br} \mathrm{J}$ Clin Pharmacol. 19881;26(1):1-5.

8. Gupta P, Udupa A. Adverse drug reporting and pharmacovigilance: knowledge, attitude and perception among resident doctors. J Pharm Sci Res. 2011;3(2):1064-6.

9. Desai CK, Iyer G, Panchal J, Shah S, Dikshit RK. An evaluation of knowledge, attitude, and practice of adverse drug reaction reporting among prescribers at a tertiary care hospital. Perspect Clin Res. 2011;2(4):129-36.

10. Palaian S, Ibrahim MI, Mishra P. Health professionals' knowledge, attitude and practices towards pharmacovigilance in Nepal. Pharm Pract. (Granada). 2011;9(4):228-35.

11. Beedimani RS, Zaman SU, Darbha S, Potturi SC. An evaluation of knowledge, attitude and practice of pharmacovigilance among medical students and 
doctors at a tertiary care hospital. Int J Basic Clin Pharmacol. 2018;7:324-32.

12. Chopra D, Wardhan N, Rehan HS. Knowledge, attitude and practices associated with adverse drug reaction reporting amongst doctors in a teaching hospital. Int J Risk Saf Med. 2011;23(4):227-32.
Cite this article as: Roshi, Tandon VR, Gupta BM. Knowledge, attitude and practices about adverse drug reaction among medical students in a medical college: an observational study. Int J Basic Clin Pharmacol 2019;8:1510-3. 